\title{
Reproducible methods for experimental infection with Flavobacterium psychrophilum in rainbow trout Oncorhynchus mykiss
}

\author{
Lone Madsen*, Inger Dalsgaard \\ Danish Institute for Fisheries Research, Fish Disease Laboratory, The Royal Veterinary and Agricultural University, \\ Stigbøjlen 4, DK-1870 Frederiksberg C, Denmark
}

\begin{abstract}
Experiments were done in order to achieve a reproducible method that can be used to infect rainbow trout Oncorhynchus mykiss with Flavobacterium psychrophilum, the causal agent of coldwater disease and rainbow trout fry syndrome. The main method investigated was intraperitoneal injection, and this method was tested using isolates with different elastin-degrading profiles and representing different serotypes. Injecting trout, average weight $1 \mathrm{~g}$, with $10^{4} \mathrm{CFU}$ (colony-forming units) per fish caused cumulative mortalities around 60 to $70 \%$. The virulent strains belonged to certain serotypes and degraded elastin. The intraperitoneal injection challenge method could be used on larger fish, but the infection dose was $10^{7}$ CFU per fish before mortalities occurred. Bath infection and bath infection in combination with formalin treatment (stress) seemed to be reproducible methods that could be used as alternatives to the intraperitoneal method, although the mortalities among infected trout were lower. The results of investigated methods were influenced by parameters such as the challenge isolate, number of fish in the tank affecting the infection pressure, origin of fish and weight of fish.
\end{abstract}

KEY WORDS: Flavobacterium psychrophilum - Experimental infection - Intraperitoneal challenge Bath challenge $\cdot$ Stress + bath challenge Cohabitation challenge Rainbow trout

\section{INTRODUCTION}

Flavobacterium psychrophilum (Bernardet et al. 1996) (synonyms Cytophaga psychrophila, Flexibacter psychrophilus) has been known as a cause of fish disease since the 1940s (Borg 1948). Primarily it affects juvenile salmonid fish. In the USA, the disease is known as low-temperature disease or coldwater disease (Borg 1960). In Denmark, infection of farmed rainbow trout Oncorhynchus mykiss by $F$. psychrophilum (referred to as rainbow trout fry syndrome [RTFS]) has been observed in freshwater aquaculture facilities since the 1980s, resulting in high mortalities in affected fry (Lorenzen et al. 1997).

The use of vaccination to control Flavobacterium psychrophilum infection is desirable. However, the

•E-mail: lom@kvl.dk development of a vaccine is dependent on reproducible challenge methods so the potency of potential vaccines can be investigated. Furthermore, reliable challenge test methods would prove useful for studying pathogenesis and for identifying virulent strains of F. psychrophilum. Ideally, the method should establish infection in most but not all of the fish challenged (Borg 1948). Several authors have used challenge methods with F. psychrophilum (Borg 1948, Otis 1984, Holt 1987. Chua 1991, Lorenzen 1994, Rangdale 1995), but so far only limited work has been done to standardise the challenge methods. The intraperitoneal (i.p.) injection method was used by Holt (1987), Chua (1991), Lorenzen (1994) and Rangdale (1995). Only Rangdale did a comparative study between different $F$. psychrophilum isolates, where $0.8 \mathrm{~g}$ rainbow trout were injected with approximately $10^{6}$ cells fish ${ }^{-1}$ resulting in mortalities varying from 17 to $74 \%$ among the tested isolates; however, the reproducibility of the method 
was not mentioned. Borg (1948) was able to produce disease in coho salmon Oncorhynchus kisutch when $F$. psychrophilum was injected intramuscularly (i.m.), although the reproducibility was poor. When Borg (1948) tested cohabitation and bath challenge methods, the fish only contracted the disease if they were scarified before the challenge. Holt (1987) and Rangdale (1995) also tested a bath challenge method where groups of rainbow trout and coho salmon, respectively, were dipped in bacterial suspensions. Both found that the disease could be reproduced in the fish, but Holt found that the method was not reproducible. Holt (1987) also tested i.p., subcutaneous and i.m. injection challenges, but preferred the subcutaneous challenge as this method was more related to natural exposure of the bacteria.

Virulence mechanisms in Flavobacterium psychrophilum have been reviewed by Dalsgaard (1993), and it has been suggested that the virulence of an isolate depends on the serotype and the proteolytic nature of the isolate (Madsen \& Dalsgaard 1998). According to Lorenzen \& Olesen (1997), the isolates they studied could be divided into 3 serotypes, $\mathrm{Fp}^{\mathrm{T}}$, Fd and Th, where the type strain NCMB 1947 belonged to $F p^{T}$. Lorenzen \& Olesen (1997) suggested that isolates belonging to serotype $\mathrm{Fp}^{\mathrm{T}}$ were less virulent than other isolates. Another important virulence factor is the ability of the isolate to degrade elastin. Madsen \& Dalsgaard (1998) found that elastin-degrading isolates were more virulent than isolates that did not degrade elastin.

The aim of this study was to develop reliable test methods that can be used to challenge rainbow trout with Flavobacterium psychrophilum. The main method investigated was i.p. injection which was tested on isolates with different elastin-degrading profiles and representing different serotypes. Bath infection, bath infection in combination with a stress factor (formalin treatment) and cohabitation were also tested.

\section{MATERIALS AND METHODS}

Bacterial strains. A Danish Flavobacterium psychrophilum strain, 950106-1/1, isolated from a rainbow trout during a clinical outbreak of RTFS in a freshwater farm in 1995, was used both in the i.p. challenge experiments and when the other challenge methods were examined. This strain represented the serotype Fd (Lorenzen \& Olesen 1997) and it degraded elastin (Madsen \& Dalsgaard 1998). The i.p. challenge method was also studied on 3 other strains. The elastin-degrading strain 99/1A and the elastinnon-degrading strain $99 / 10 \mathrm{~A}$ were isolated on the same fish farm (Madsen \& Dalsgaard 1998). However,
99/10A belonged to serotype $F p^{T}$ (Lorenzen \& Olesen 1997 ) and 99/1 A agglutinated antisera against serotypes $\mathrm{Fd}$ and $\mathrm{Fp}^{\mathrm{T}}$, although earlier investigations had shown that it belonged to serotype $\mathrm{Fp}^{\mathrm{T}}$ (Madsen \& Dalsgaard 1998). The serotype Th (Lorenzen \& Olesen 1997) was represented by the elastin-degrading strain $900406-1 / 3$ that was isolated from a $100 \mathrm{~g}$ rainbow trout with coldwater disease in 1990. The 4 strains were stored in 15 to $20 \%$ glycerol at $-80^{\circ} \mathrm{C}$. Bacteria used for the experiments were inoculated directly from $-80^{\circ} \mathrm{C}$ into $10 \mathrm{ml}$ tryptone yeast extract salts (TYES) broth (Holt et al. 1993). All broth cultures were shaken while incubated. After $72 \mathrm{~h}$ of incubation at $15^{\circ} \mathrm{C}, 0.5 \mathrm{ml}$ of the bacterial suspension was inoculated into $100 \mathrm{ml}$ TYES broth. Forty-eight hour cultures were adjusted to the absorbance 0.3 (at $525 \mathrm{~nm}$ ) using a spectrophotometer (Shimadzu UV-1201). An absorbance between 0.3 and 0.5 of a $4.8 \mathrm{~h} 100 \mathrm{ml}$ bacterial culture corresponds to bacterial counts of approximately $10^{8} \mathrm{CFU}$ (colony-forming units) $\mathrm{ml}^{-1}$. Bacterial counts expressed as CFU were determined in each experiment by the spread plate method on TYES agar (Holt 1987). The inocula used in the experiments were adjusted by diluting the bacterial cultures with TYES broth. Only in Challenge 3 were washed bacteria used and the inocula diluted in $0.9 \%$ $\mathrm{NaCl}$. Bacteria cultured $(10 \mathrm{ml})$ in TYES broth were harvested and washed twice in $0.9 \% \mathrm{NaCl}$ (3000 rpm $[\sim 1270 \times g]$ for $20 \mathrm{~min})$, then resuspended in $10 \mathrm{ml}$ $0.9 \% \mathrm{NaCl}$ whereafter bacterial counts were done.

Fish and fish tank facilities. Rainbow trout were received at our laboratory at a weight of 0.1 to $0.5 \mathrm{~g}$ and were acclimatized for at least 1 mo before the challenge experiments. The trout were fed dry commercial pellets (Ecostart 17. BioMar A/S) before and during the experiments. Replicate groups of approximately 50 rainbow trout (in Challenges 1 and 4 the groups consisted of 31 and 18 trout, respectively) (see Table 1) were kept at a temperature of $12^{\circ} \mathrm{C}$ in $30 \mathrm{l}$ tanks with separate recirculation of water and air-supply for each tank. The content of $\mathrm{NO}_{3}{ }^{-}$and $\mathrm{NO}_{2}{ }^{-}$in the water was measured by nitrate test strips (Merckoquant 10 020) to ensure that the biological filters were functioning during the experiments. Before each experiment the tanks and filters were washed and disinfected, and the filters were inoculated with material taken from filters connected to tanks with healthy stock fish. Rainbow trout that originated from 3 fish farms were used in Challenges 1 to 9. Fish from one farm were used in Challenge 1 and fish from another fish farm in Challenges 2 and 4 . Fish used in the other challenges originated from a third fish farm but from 2 successive years (fish used in Challenge 5 were from another year). The weight of the fish was 1 to $3 \mathrm{~g}$ in all experiments apart from Challenge 4, where the weight was $28 \mathrm{~g}$ (the 
average weight of fish in each challenge can be seen in Tables 1 to 3 in the 'Results'). Further descriptions of the experiments are shown in Tables 1 to 3 . Deaths were recorded daily and necropsy involved gross external and internal examinations. Mortality specificity was confirmed by aseptic removal of part of the internal organs brain, kidney and spleen of all dead and moribund fish with a sterile loop for inoculation onto TYES agar and subsequent incubation at $15^{\circ} \mathrm{C}$ for up to $10 \mathrm{~d}$. The challenge experiments were terminated after 28 or $42 \mathrm{~d}$.

I.p. injection challenge (Challenges 1 to 6). Prior to infection all fish were anaesthetized with 3-aminobenzoic acid ethyl ester (Sigma A-5040) and thereafter the fish were injected i.p. with either $0.05 \mathrm{ml}$ of a whole cell bacterial culture or $0.05 \mathrm{ml}$ sterile TYES (control). The i.p. challenges (Challenges 1 to 6 ) are described in Table 1. Fish were injected with $0.05 \mathrm{ml}$ of 10 -fold serial dilutions of each bacterial strain. The strain $950106-$ 1/1 was used in Challenges 1, 2, 3 and 4. In Challenge 3,2 of the fish groups were injected with washed bacteria in two 10 -fold serial dilutions, while the third group was injected with the whole broth culture. In Challenge 4 , the infection method was tested on duplicate groups of larger fish. In Challenge 5, the infection method was tested with 2 other strains, 99/1A and 99/10A, where duplicate groups of fish were infected with three 10 -fold dilutions of each strain. In Challenge 6 , the virulence of the strain $900406-1 / 3$ was studied. Three 10-fold dilutions of the bacterium, 2 of them in duplicate, were tested. All experiments had control tanks with fish injected i.p. with $0.05 \mathrm{ml}$ TYES broth.

Bath challenge (Challenge 7 ). In the bath challenge experiment, 100 to $200 \mathrm{ml}$ TYES broth with bacteria was diluted 1:10 with tap water. The fish were exposed to the aerated bacterial dilution $(2.0 \times$ $10^{7} \mathrm{CFU} \mathrm{m}^{-1}$ ) for $0.5 \mathrm{~h}$, before they were returned to their tank (see Table 2). Fish in the control tank were bathed for $0.5 \mathrm{~h}$ in sterile TYES broth that was diluted 1:10 with tap water.

Stress + bath challenge (Challenge 8). In the stress + bath challenge experiment, the fish were exposed to an aerated $0.005 \%$ formalin solution during $0.5 \mathrm{~h}$ before the bath infection was done (see Table 2). The fish were exposed to the aerated bacterial dilution $(2.0$ $\times 10^{8}$ and $2.0 \times 10^{7} \mathrm{CFU} \mathrm{ml}^{-1}$, respectively) for $0.5 \mathrm{~h}$. Fish in a control tank were exposed to a $0.005 \%$ formalin solution for $0.5 \mathrm{~h}$.

Cohabitation challenge (Challenge 9). The cohabitation challenge experiment was done in 2 tanks, each with 50 fish. Half of the fish in each tank were i.p. infected with a bacterial dilution (see Table 3), and the other half of the fish were marked by cutting off the adipose fin and thereafter placed in the same tank as the infected fish.

\section{RESULTS}

\section{I.p. injection challenge (Challenges 1 to 6 )}

Fig. 1 illustrates the results from 2 experiments where the i.p. challenge method was tested on 2 stocks of fish. The fish began to die on Day 2 post challenge in the groups infected with the highest doses, $2.5 \times 10^{7}$ and $4.0 \times 10^{6} \mathrm{CFU} \mathrm{fish}^{-1}$ (Challenge 1), and during the next 8 d nearly all the fish died in these 2 groups. In the groups infected with $4.5 \times 10^{5}$ (Challenge 1), $1.4 \times 10^{4}$ and $0.7 \times 10^{3} \mathrm{CFU}$ fish $^{-1}$ (Challenge 2) the mortalities started on Day 4 to 5 post challenge and continued for the next 12 to $16 \mathrm{~d}$. Apart from the fish coming from different farms, there was also a small difference in average weight of the fish used in the 2 experiments (Table 1).

Fig. 2 shows the results of Challenge 3, where the i.p. challenge method was tested with washed and unwashed bacterial cells. The mortalities started on Day 2 post challenge and continued for the next $20 \mathrm{~d}$. In the 2 groups infected with comparable dilutions of washed and un-washed bacteria, the cumulative mortalities on Day 28 post challenge were 71 and $78 \%$, respectively (Table 1). These results were not statistically different (chi-square test, $\mathrm{p}>0.05$ ).

Fig. 3 and Table 1 shows the results of Challenge 4 , where the i.p. challenge method was tested on larger fish. The mortalities started on Days 3 and 8 post challenge in the 2 groups injected with $2.0 \times 10^{7} \mathrm{CFU} \mathrm{fish}^{-1}$, and continued until Day 14. Mortality occurred in only 1 of the 2 groups injected with $2.4 \times 10^{5} \mathrm{CFU} \mathrm{fish}^{-1}$, namely on Day 18 post challenge. No statistical difference was seen among the duplicate tanks ( $p>0.05)$

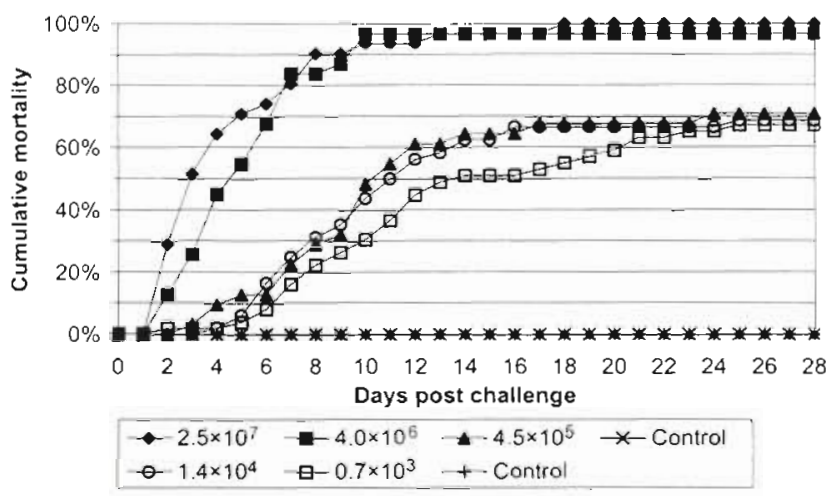

Fig. 1. Challenges 1 and 2: cumulative mortalities among rainbow trout following intraperitoneal injection with different doses (CFU fish ${ }^{-1}$ ) of the Flavobacterium psychrophilum isolate 950106-1/1. In Challenge 1 each group consisted of 31 trout, average weight $1.5 \mathrm{~g}$ (first 4 groups in the legend, upper row), while each group consisted of approx. 50 trout, average weight $1.1 \mathrm{~g}$ (last 3 groups in the legend, bottom row) in Challenge 2 
Table 1 Flavobacterium psychrophilium infecting Oncorhynchus mykiss. Intraperitoneal (i.p.) challenge experiments

\begin{tabular}{|c|c|c|c|c|}
\hline $\begin{array}{c}\text { Challenge } \\
\text { no. }\end{array}$ & $\begin{array}{l}\text { Challenge } \\
\text { isolate } \\
\text { (serotype/ } \\
\text { elastin- } \\
\text { degradation) }\end{array}$ & $\begin{array}{l}\text { Challenge } \\
\text { dose } \\
\text { (CFU fish }\end{array}$ & $\begin{array}{c}\text { No. of } \text { fish }^{a} / \\
\text { average } \\
\text { weight } \\
\text { (g) }\end{array}$ & $\begin{array}{l}\text { Cumulative } \\
\text { mortality } \\
28 \text { d post } \\
\text { challenge } \\
(\%)\end{array}$ \\
\hline 1 & $\begin{array}{l}\text { Fd / elast }+ \\
(950106-1 / 1)\end{array}$ & $\begin{array}{l}2.5 \times 10^{7} \\
4.0 \times 10^{6} \\
4.5 \times 10^{5}\end{array}$ & $\begin{array}{l}31 / 1.5 \\
31 / 1.5 \\
31 / 1.5\end{array}$ & $\begin{array}{r}100 \\
97 \\
71\end{array}$ \\
\hline 2 & $\begin{array}{c}\text { Fd / elast+ } \\
(950106-1 / 1)\end{array}$ & $\begin{array}{l}1.4 \times 10^{4} \\
0.7 \times 10^{3}\end{array}$ & $\begin{array}{l}48 / 1.1 \\
49 / 1.1\end{array}$ & $\begin{array}{l}69 \\
67\end{array}$ \\
\hline 3 & $\begin{array}{c}\text { Fd / elast }+ \\
(950106-1 / 1)\end{array}$ & $\begin{array}{l}2.5 \times 10^{4} \\
2.5 \times 10^{4} \mathrm{~b} \\
2.5 \times 10^{3} \mathrm{~b}\end{array}$ & $\begin{array}{l}55 / 1.5 \\
52 / 1.5 \\
51 / 1.5\end{array}$ & $\begin{array}{l}78 \\
71 \\
53\end{array}$ \\
\hline 4 & $\begin{array}{c}\text { Fd / elast+ } \\
(950106-1 / 1)\end{array}$ & $\begin{array}{l}2.0 \times 10^{7} \\
2.4 \times 10^{5}\end{array}$ & $\begin{array}{l}18,18^{c / 28} \\
18,18^{c / 28}\end{array}$ & $\begin{array}{c}28 / 22 \\
0 / 6\end{array}$ \\
\hline 5 & $\begin{array}{c}\text { Fd and } F p^{\top} / \\
\text { elast+ } \\
(99 / 1 \mathrm{~A})\end{array}$ & $\begin{array}{l}1.0 \times 10^{6} \\
1.0 \times 10^{5} \\
1.0 \times 10^{4}\end{array}$ & $\begin{array}{l}49,51^{c} / 1.3 \\
48,48^{c} / 1.3 \\
49,49^{c} / 1.3\end{array}$ & $\begin{array}{l}98 / 96 \\
92 / 98 \\
71 / 82\end{array}$ \\
\hline & $\begin{array}{l}F p^{\top} / \text { elast - } \\
\text { (99/10A) }\end{array}$ & $\begin{array}{l}1.6 \times 10^{6} \\
2.0 \times 10^{5} \\
1.0 \times 10^{4}\end{array}$ & $\begin{array}{l}49,45^{c} / 1.3 \\
46,49^{c} / 1.3 \\
47,52^{c / 1.3}\end{array}$ & $\begin{array}{l}77 / 67 \\
20 / 7 \\
8 / 6\end{array}$ \\
\hline 6 & $\begin{array}{c}\text { Th, elast+ } \\
(900406-1 / 3)\end{array}$ & $\begin{array}{l}2.0 \times 10^{6} \\
2.0 \times 10^{5} \\
2.0 \times 10^{4}\end{array}$ & $\begin{array}{c}51 / 1.0 \\
48,51^{c / 1} / 0 \\
48,47^{c / 1} / 0\end{array}$ & $\begin{array}{c}98 \\
94 / 90 \\
92 / 89\end{array}$ \\
\hline \multicolumn{5}{|c|}{$\begin{array}{l}{ }^{a} \text { Challenges were done on groups of approximately } 50 \text { trout, except } \\
\text { Challenges } 1 \text { and } 4 \text {, where groups consisted of } 31 \text { and } 18 \text { trout, respec- } \\
\text { tively. Some fish did not survive the first few hours after the infection, } \\
\text { and these fish are not counted in the no. of fish tested in each challenge } \\
{ }^{\circ} \text { Bacteria washed in } 0.9 \% \mathrm{NaCl} \text { twice before injection } \\
\text { 'Challenges done in duplicate }\end{array}$} \\
\hline
\end{tabular}

The results of the i.p. challenge method tested on 2 strains with difference in both elastin-degrading profile and serotype (Challenge 5) are shown in Table 1. Chisquare tests were done on the mortality results from replicate tanks. No statistical differences were found between replicates ( $p>0.05)$. Fig. 4 (Challenge 5) shows the mortalities during the whole challenge period among the groups that were injected with $1.0 \times 10^{4} \mathrm{CFU}_{\mathrm{fish}}{ }^{-1}$ of the 2 isolates. The mortalities in these groups started around Day 4 and continued for $18 \mathrm{~d}$.

Fig. 5 shows the results of the i.p. challenge method tested on an isolate belonging to serotype Th (Challenge 6). The mortalities started on Day 2 post challenge in all groups and continued for $16 \mathrm{~d}$. No statistical differences among the duplicate tanks were found.

In each challenge experiment, 1 or 2 control groups were included where the fish were injected i.p. with TYES broth. The fish were able to survive the anaesthesia and an i.p. injection of the TYES broth, as there were no deaths in these groups during the experiments, apart from Challenge 6 , where the cumulative mortality among the control fish reached $12 \%$ on Day 28.

It was possible to isolate Flavobacterium psychrophilum from at least 1 of the 3 organs (spleen, kidney, or brain) of dead fish in Challenges 1,2 and 4 . In Challenge 3 the bacterium could not be isolated from 4 and 6 dead fish, respec-

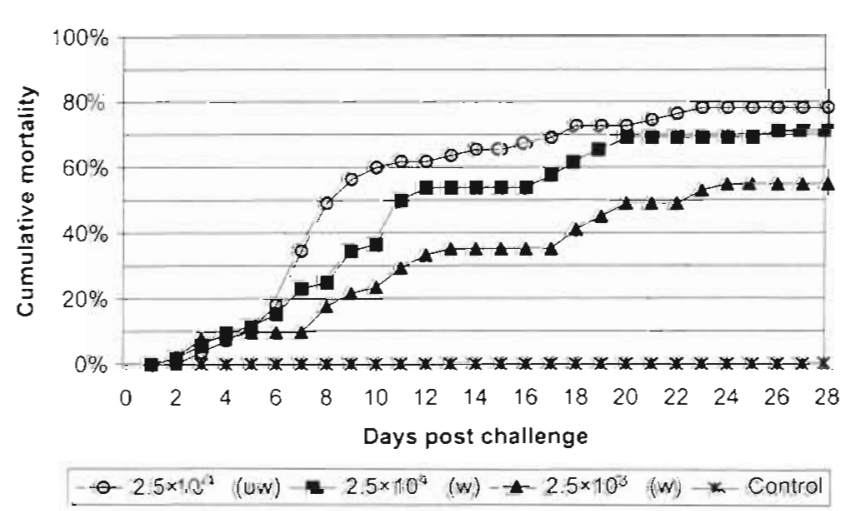

Fig. 2. Challenge 3: cumulative mortalities among rainbow trout (approx. 50 trout per group, average weight $1.5 \mathrm{~g}$ ) following intraperitoneal injection with doses (CFU fish ${ }^{-1}$ ) of the Flavobacterium psychrophilum isolate 950106-1/1, where the isolate was either washed (w) or un-washed (uw)

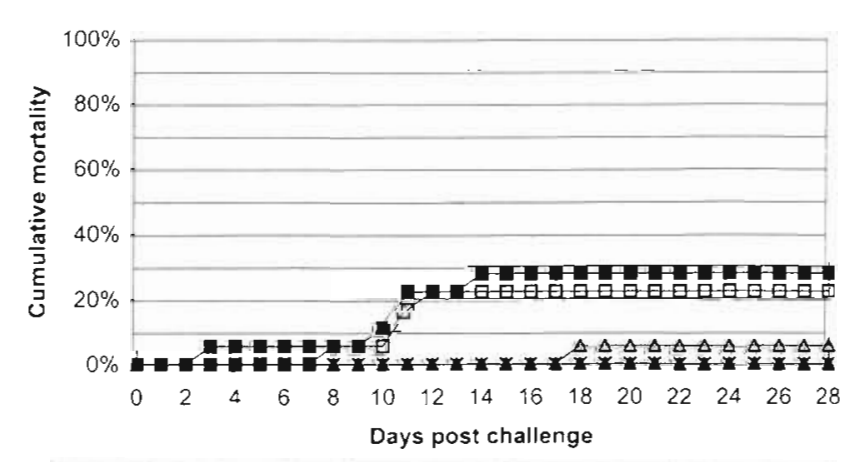

$2.0 \times 10^{7} \quad \square-2.0 \times 10^{7}-2.4 \times 10^{5} \quad \Delta 2.4 \times 10^{5} \rightarrow$ Control

Fig. 3. Challenge 4: cumulative mortalities among rainbow trout, 18 trout per group, average weight $28 \mathrm{~g}$, following intraperitoneal injection with different doses (CFU fish ${ }^{-1}$ ) of Flavobacterium psychrophilum isolate 950106-1/1 


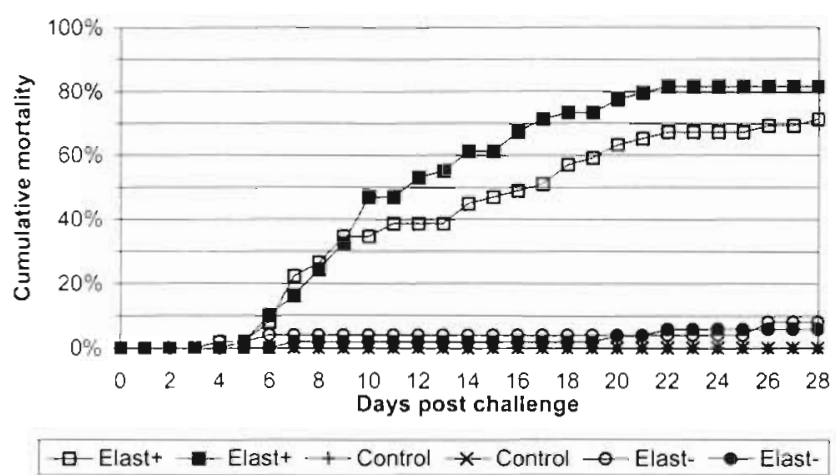

Fig. 4. Challenge 5: cumulative mortalities among rainbow trout (approx. 50 trout per group, average weight $1.3 \mathrm{~g}$ ) following intraperitoneal injection with elastin-degrading isolate 99/1 A (elast+) and elastin-non-degrading isolate 99/10A (elast-) of Flavobacterium psychrophilum (both in duplicate), dose $1.0 \times 10^{4} \mathrm{CFU} \mathrm{fish}^{-1}$

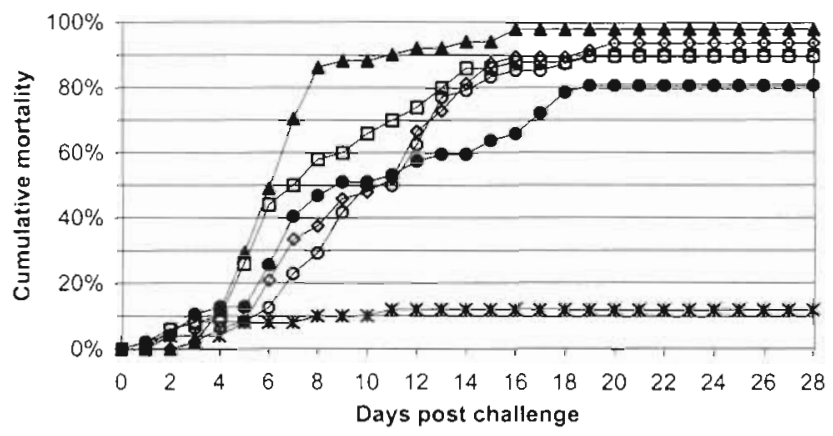

$-2 \times 10^{6} \square 2 \times 10^{5}-2 \times 10^{5}-2 \times 10^{4}-\odot-2 \times 10^{4}-*$ - Control

Fig. 5. Challenge 6: cumulative mortalities among rainbow trout (approx. 50 trout per group, average weight $1.0 \mathrm{~g}$ ) following intraperitoneal injection with different doses (CFU fish $^{-1}$ ) of the Flavobacterium psychrophilum isolate 900406$1 / 3$ representing the serotype Th

tively, in the 2 groups infected with the washed bacteria, and from 9 dead fish in the group infected with the whole broth culture. It was not possible to isolate the bacterium from 12 and 3 dead fish, respectively, in the 2 groups infected with the high dose of the elastin-negative strain in Challenge 5, and in Challenge 6 F. psychrophilum could not be isolated from 3 to 15 dead fish in each of the groups. In all these cases, the dead fish were decayed and the agar plates were overgrown by other bacteria after 2 to $3 \mathrm{~d}$ of incubation. No F. psychrophilum were isolated from the dead control fish in Challenge 6.

An enlarged and friable spleen was noted when observing the internal organs of the dead fish in the injection experiments. The posterior kidney was swollen and there was ascites with haemorrhage on peritoneum and the abdominal organs in some of the fish. Haemorrhage around the injection site was observed on some of the fish.

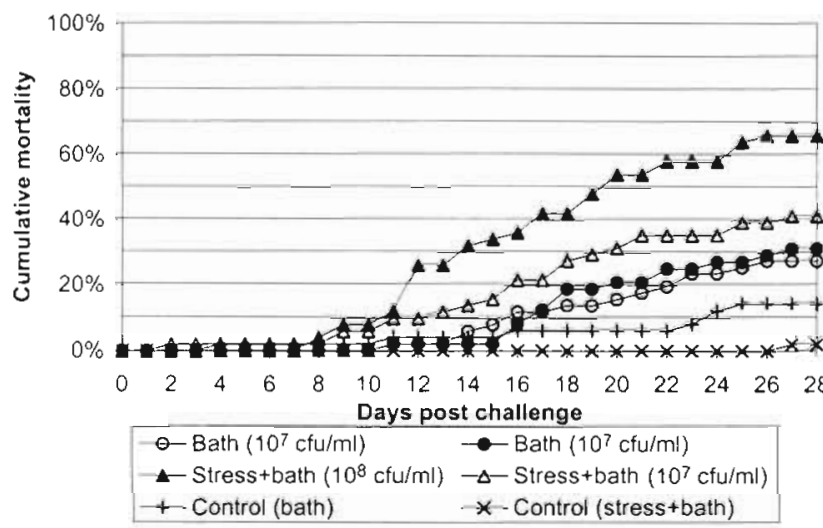

Fig. 6. Challenges 7 and 8: cumulative mortalities among rainbow trout (approx. 50 trout per group, average weight $1.0 \mathrm{~g}$ ), either following bath challenge with Flavobacterium psychrophilum or first formalin treatment $(0.005 \%)$ and then bath challenge. The elastin-degrading isolate 950106-1/1, belonging to serotype $\mathrm{Fd}$, was used in both challenge experiments

\section{Bath challenge (Challenge 7)}

The results of the bath challenge experiment (Challenge 7) are shown in Fig. 6 and Table 2. The fish started to die on Day 11 post challenge and the mortalities rose for the next $12 \mathrm{~d}$. Flavobacterium psychrophilum was isolated from 11 of 14 dead fish in one group and from 11 of 15 dead fish in the other group. Seven of 49 control fish died during the experiment. F. psychrophilum was not isolated from these fish.

\section{Stress + bath challenge (Challenge 8)}

The results of the stress + bath challenge experiment (Challenge 8) are shown in Fig. 6 and Table 2. The mortalities started around Day 8 post challenge (except from 1 fish in the group bathed in the $2.0 \times 10^{7}$ CFU mi $\mathrm{m}^{-1}$ suspension that died on Day 2), and mortalities rose for the next $17 \mathrm{~d}$. Flavobacterium psychrophilum was isolated from 32 of 33 dead fish in the group that had been exposed to $2.0 \times 10^{8} \mathrm{CFU} \mathrm{ml} \mathrm{m}^{-1}$ while F. psychrophilum was isolated from 17 of 21 dead fish that had been exposed to $2.0 \times 10^{7} \mathrm{CFU} \mathrm{ml}{ }^{-1}$. One of 50 control fish died during the experiment and F. psychrophilum was not isolated from that fish.

\section{Cohabitation challenge (Challenge 9)}

Fig. 7 and Table 3 show the results of the cohabitation challenge experiment. The i.p. infected fish started to die on Day 4 post challenge and the mortalities rose for the next $14 \mathrm{~d}$, while the mortalities among 
Table 2. Flavobacterium psychrophilium infecting Oncorhynchus mykiss. Bath challenge experiments

\begin{tabular}{|c|c|c|c|c|c|c|}
\hline Challenge no. & $\begin{array}{c}\text { Formalin } \\
\text { dose } \\
(\%)\end{array}$ & $\begin{array}{c}\text { Challenge } \\
\text { isolate }^{a} \\
\text { (serotype / } \\
\text { elastin- } \\
\text { degradation) }\end{array}$ & $\begin{array}{c}\text { Challenge dose } \\
\mathrm{ml}^{-1} \text { water } \\
\left.\text { (CFU ml } \mathrm{ml}^{-1}\right)\end{array}$ & $\begin{array}{l}\text { Duration } \\
\text { of bath } \\
\text { (h) }\end{array}$ & $\begin{array}{c}\text { No of fish / } \\
\text { average weight } \\
\text { (g) }\end{array}$ & $\begin{array}{c}\text { Cumulative } \\
\text { mortality } \\
28 \mathrm{~d} \text { post } \\
\text { challenge } \\
(\%)\end{array}$ \\
\hline 7 & $\begin{array}{l}- \\
-\end{array}$ & $\begin{array}{l}\mathrm{Fd} / \text { elast }+ \\
\mathrm{Fd} / \text { elast }\end{array}$ & $\begin{array}{l}2.0 \times 10^{7} \\
2.0 \times 10^{7}\end{array}$ & $\begin{array}{l}0.5 \\
0.5\end{array}$ & $\begin{array}{l}51 / 1.0 \\
48 / 1.0\end{array}$ & $\begin{array}{l}27 \\
31\end{array}$ \\
\hline 8 & $\begin{array}{l}0.005 \\
0.005\end{array}$ & $\begin{array}{l}\text { Fd / elast }+ \\
\text { Fd / elast }\end{array}$ & $\begin{array}{l}2.0 \times 10^{8} \\
2.0 \times 10^{7}\end{array}$ & $\begin{array}{l}0.5 \\
0.5\end{array}$ & $\begin{array}{l}50 / 1.0 \\
51 / 1.0\end{array}$ & $\begin{array}{l}66 \\
41\end{array}$ \\
\hline
\end{tabular}

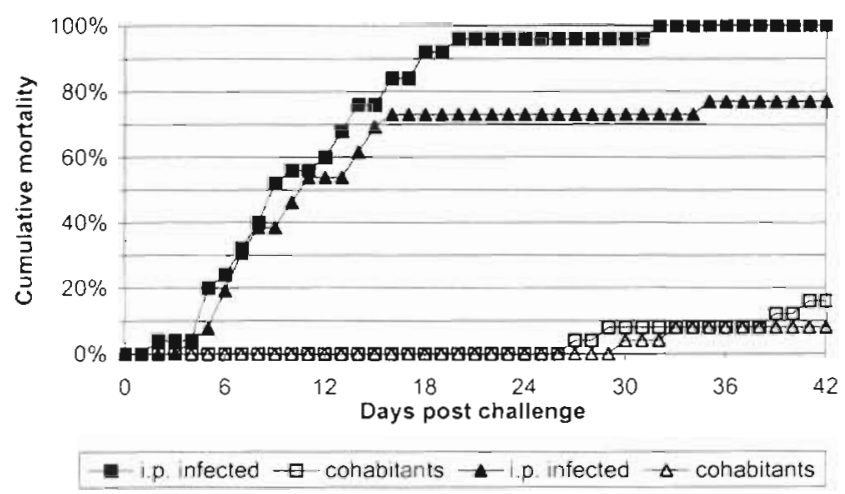

Fig. 7. Challenge 9: cumulative mortalities among 2 groups of rainbow trout (50 trout per group, average weight $1.0 \mathrm{~g}$ ). Twenty-five of the fish in each group were intraperitoneally infected (dose $1.2 \times 10^{4} \mathrm{CFU}_{\text {fish }}{ }^{-1}$ ) with Flavobacterium psychrophilum (950106-1/1, serotype Fd) and the other 25 were left untreated

the cohabitants started around Day 27. Flavobacterium psychrophilum was isolated from 21 out of 25 dead i.p. infected fish, while the bacterium was jsolated from 3 of the 4 dead cohabitants in Replicate 1. In Replicate 2, the bacterium was isolated from 18 of 20 dead i.p. infected fish, while the bacterium could not be isolated from either of the 2 dead cohabitants.

Table 3. Flavobacterium psychrophilium infecting Oncorhynchus mykiss. Cohabitation challenge experiment

\begin{tabular}{|ccccc|}
\hline $\begin{array}{c}\text { Challenge } \\
9\end{array}$ & $\begin{array}{c}\text { Challenge } \\
\text { isolate } \\
\text { (serotype/ } \\
\text { elastin- } \\
\text { degradation) }\end{array}$ & $\begin{array}{c}\text { Challenge } \\
\text { dose } \\
(\text { CFU mi }\end{array}$ & $\begin{array}{c}\text { No. of fish/ } \\
\text { average } \\
\text { weight } \\
(\mathrm{g})\end{array}$ & $\begin{array}{c}\text { Cumulative } \\
\text { mortality } \\
42 \text { d post } \\
\text { challenge } \\
(\%)\end{array}$ \\
\hline Replicate 1 & Fd/ elast+ & $1.2 \times 10^{4}$ & $25 / 1.0$ & 100 \\
Replicate 2 & Fd / elast+ & - & $25 / 1.0$ & 16 \\
a 950106-1/1 used in the challenge & $-2 \times 10^{4}$ & $25 / 1.0$ & 80 \\
\end{tabular}

\section{DISCUSSION}

A reproducible i.p. injection challenge method has been developed for causing disease by Flavobacterium psychrophilum in rainbow trout. Injecting trout, average weight $1 \mathrm{~g}$, with $10^{4} \mathrm{CFU}$ fish ${ }^{-1}$ results in a cumulative mortality of around 60 to $70 \%$. Our results fulfil the recommendations made by Amend (1981) that the cumulative mortality in an infected group has to be around 60 to $85 \%$ for evaluation of the significance of an experimentally applied infection. The cumulative mortalities (71 and $69 \%$ ) in groups infected with $4.5 \times$ $10^{5} \mathrm{CFU} \mathrm{fish}^{-1}$ in Challenge 1 and $1.4 \times 10^{4} \mathrm{CFU}_{\text {fish }}{ }^{-1}$ in Challenge 2 are similar, although the infection dose in Challenge 1 was 10 times higher than the infection dose used in Challenge 2. This may be due to the fact that the fish used in the 2 challenge experiments originated from different fish farms and may have had different immune status. Furthermore, the average weight of the fish was slightly higher and the number of fish in tanks lower in Challenge 1 compared to Challenge 2 (Table 1). Fish used in Challenge 3 originated from a third fish farm. The mortalities in groups infected with a challenge dose of $10^{4} \mathrm{CFU} \mathrm{fish}^{-1}$ in Challenge 3 are comparable to mortalities in groups infected with the same challenge dose in Challenge 2

(Table 1), although the average fish weight was higher in Challenge 3 and the same as the average fish weight in Challenge 1 . This suggests that the mortality was more dependent on both fish origin and number of fish $I^{-1}$ in tanks affecting the infection pressure than a weight difference between 1.1 and $1.5 \mathrm{~g}$ among fish.

The i.p. injection challenge method could be used on larger fish as well, but the infection dose had to be approximately $10^{7} \mathrm{CFU} \mathrm{fish}^{-1}$ or higher before mortalities occurred in the infected groups, although the recommendation on mortality rates made by Amend (1981) 
was not reached. Trout fry were much more sensitive to infection with Flavobacterium psychrophilum than larger trout. This observation is supported by the mortality rates seen on fish farms during disease outbreaks, where the mortalities among fry are much higher (up to $80 \%$ ) than among fingerlings and larger fish (20\%) (Lorenzen 1994).

Washing the bacterial cells did not alter the mortality rate (Challenge 3) when the i.p. injection challenge method was used. This is supported by the results of Rangdale (1995), which reported high mortality in fish when washed Flavobacterium psychrophilum isolates were injected i.p.

Comparison of Flavobacterium psychrophilum isolates with different elastin-degrading profiles showed that the elastin-degrading isolate was much more virulent than the isolate with the elastin-non-degrading profile (Fig. 4), as reported previously (Madsen \& Dalsgaard 1998). A large gap in the mortalities among the groups infected with $10^{5} \mathrm{CFU}_{\text {fish }}{ }^{-1}$ and $10^{6} \mathrm{CFU}_{\text {fish }}{ }^{-1}$ of the elastin-non-degrading isolate was seen. Our investigations cannot explain the reason for this gap, but the high mortalities in the groups infected with $10^{6}$ CFU fish ${ }^{-1}$ of the elastin-non-degrading isolate may be associated with the exposure to massive quantities of foreign proteins as suggested by Chua (1991) and Rangdale (1995).

Elastin-degrading isolates that belonged to different serotypes seem to have identical virulence properties. Injection of $10^{4} \mathrm{CFU}$ fish $^{-1}$ of isolates that belonged to the serotypes Fd and Th resulted in mortalities around $70 \%$ (Challenge 2) and 90\% (Challenge 6), respectively, compared to $75 \%$ for the isolate that agglutinated antisera against both $\mathrm{Fd}$ and $\mathrm{Fp}^{\mathrm{T}}$ (Challenge 5).

The reproducible i.p. challenge method can be used to investigate potential vaccines but the i.p. injection of infectious agents may not be an entirely appropriate method of testing for pathogenicity, as this method bypasses the non-specific immune mechanisms located in the skin, such as mucus lysozyme and skinassociated phagocytes. These non-specific defence mechanisms remain intact when bath infection and cohabitation challenges that most closely mimic natural exposure to a pathogen are used (Bricknell 1995, Nordmo 1997). However, these methods are more difficult to control and standardise than injection methods (Nordmo 1997). Our study showed that bath challenge with Flavobacterium psychrophilum resulted in infection of the trout. Borg (1948) tested bath challenge, but the infection only succeeded if the fish were scarified in connection with the challenge. Holt (1987) also bath challenged groups of coho salmon that were dipped in suspensions of $10^{6}$ and $10^{8}$ cells $\mathrm{ml}^{-1}$ for $10 \mathrm{~min}$, some of the fish with a fresh wound (adipose fin clip). Holt was able to produce disease in both groups of fish (not higher mortalities in the groups of fish with fresh wounds). Chua (1991) and Rangdale (1995) were able to infect fish by bath challenge. The water quality had deteriorated before infection and the final concentration of bacteria in the bath at the end of the infection period was $10^{5} \mathrm{CFU} \mathrm{m} \mathbf{l}^{-1}$ (Rangdale 1995). After $2 \mathrm{wk}$, $30 \%$ of the fish dipped for $5 \mathrm{~h}$ and $40 \%$ of the fish dipped for $10 \mathrm{~h}$ had died. In accordance with the observations by Rangdale (1995), we found cumulative mortalities of 27 to $31 \%$ in our bath challenge experiment; however, we used the infection dose $10^{7} \mathrm{CFU} \mathrm{ml} \mathrm{ml}^{-1}$ and the fish were dipped for only $0.5 \mathrm{~h}$. Preliminary studies (authors' unpubl. data) resulted in cumulative mortalities 4 wk post challenge on 28 and $7 \%$ among 2 groups of fish (average weight $2.1 \mathrm{~g}$ ), the challenge dose $\mathrm{ml}^{-1}$ water being $2.0 \times 10^{7} \mathrm{CFU}$. The same bath was used for both groups, the group with the highest mortality rate being the first group to be bathed. One suggested reason for the difference in mortalities might be that the fish secrete mucus in the bath which neutralises some of the bacteria, and some of the bacteria stick to the fish, the result of which is that the challenge dose is lower for fish in the second group. The $28 \%$ mortality in the experiment where fish were dipped in a $2.0 \times 10^{7}$ CFU $\mathrm{ml}^{-1}$ bacterial solution matches the results of Challenge 7 (Table 2), although the average weight in the 2 experiments were 2.1 and $1.0 \mathrm{~g}$, respectively. This suggests reproducibility of the bath challenge method with F. psychrophilum, when the method is used on fish with a size of 1 to $2 \mathrm{~g}$

The stress + bath challenge method seems to be a more efficient method compared to bath challenge alone, as the mortalities are higher. The cumulative mortality among fish that were stressed and bathed in a bacterial suspension of $10^{8} \mathrm{CFU} \mathrm{\textrm {ml } ^ { - 1 }}$ fulfill the recommandations made by Amend (1981). The results obtained so far indicate that the combination of stress together with a bath challenge will be a possible alternative to the injection challenge. However, further experiments are needed.

The cohabitation model did not appear to be a method that could be used for challenging rainbow trout fry with Flavobacterium psychrophilum, supporting the findings of Holt (1987). Borg (1948) also studied cohabitation in an experiment in which he transferred healthy fish to fish that had been i.m. infected and that had lesions on their sides. The healthy fish did not contract the infection, but when the fish were scarified, some were infected. In Borg's experiments the fish were 6 to $9 \mathrm{~cm}$, while our fish were $1.0 \mathrm{~g}$ and approximately $4.5 \mathrm{~cm}$ long. In our experiment only a few cohabitants contracted the disease, although the infection rate reached 80 to $100 \%$ among the i.p. infected fish. A preliminary experiment (authors' unpubl. data) showed the same tendency, although the mortalities 
reached 77 and $74 \%$, respectively, among the fish infected i.p. with $10^{5} \mathrm{CFU} \mathrm{fish}^{-1}$, and were 4 and $0 \%$, respectively, among their cohabitants. The average weight for trout used in the preliminary experiment was $2.9 \mathrm{~g}$ while it was only $1.0 \mathrm{~g}$ in the described challenge in Table 3 . The reason for the lower mortalities among the i.p. infected fish in the preliminary experiment compared to the cohabitation challenge, despite the fact that the infection dose was 10 times higher, might be due to this difference in average weight and thereby immunocompetence among fish used in the 2 experiments. The development of lymphoid organs in fish correlates better with the weight of the fish than with age (Ellis 1988). Furthermore, body size is more important in determining immunological maturation than age (Tatner 1996), and the ability of salmonid fish to develop prolonged duration of protection upon vaccination is fully developed when the fry are about $4 \mathrm{~g}$ (Ellis 1988).

In conclusion, this study showed that the i.p. injection challenge method with Flavobacterium psychrophilum was reproducible in rainbow trout fry. This method may not be an appropriate way of testing for pathogenicity as it bypasses the non-specific immune mechanisms in the skin of the host. A method more related to natural exposure of the fish to bacteria is the bath challenge method (with/without stress) and our results showed that this method seems to have a degree of reproducibility, although the mortality rates are lower compared to the mortality rates following i.p. infection. The results of the investigated methods are highly influenced by parameters such as virulence of the challenge isolate, number of fish in the tank affecting the infection pressure, origin of fish and weight of fish.

Acknowledgements. The skillful technical assistance of Kirsten Kaas, Ann Charlot Ejsing and Charlotte Wittchen is very much appreciated. We thank Jens Laurits Larsen for reviewing the manuscript. This study was supported by the Danish Research Academy, Danish Institute for Fisheries Research and the Organization of Danish Aquaculture.

\section{LITERATURE CITED}

Amend DF (1981) Potency testing of fish vaccines. Dev Biol Stand 49:447-454

Bernardet JF, Segers P, Vancanneyt M, Berthe F, Kersters K, Vandamme P (1996) Cutting a Gordian knot: emended

Editorial responsibility: David Bruno,

Aberdeen, Scotland, UK classification and description of the Genus Flavobacterium, emended description of the Family Flavobacteriaceae, and proposal of Flavobacterium hydatis nom. nov. (Basonym, Cytophaga aquatilis Strohl and Tait 1978). Int J Syst Bacteriol 46:128-148

Borg AF (1948) Studies on myxobacteria associated with diseases in salmonid fishes. PhD thesis, University of Washington, Seattle

Borg AF (1960) Studies on myxobacteria associated with diseases in salmonid fishes. J Wildl Dis 8:1-85

Bricknell (1995) A reliable method for induction of experimental furunculosis. J Fish Dis 18:127-133

Chua FHC (1991) A study of the Rainbow Trout Fry Syndrome. MSc thesis, Stirling University

Dalsgaard I (1993) Virulence mechanisms in Cytophaga psychrophila and other Cytophaga-like bacteria pathogenic for fish. Annu Rev Fish Dis 1:127-144

Ellis AE (1988) Ontogeny of the immune system in teleost fish In: Ellis AE (ed) Fish vaccination. Academic Press, London, p 20-31

Holt RA (1987) Cytophaga psychrophila, the causative agent of bacterial cold-water disease in salmonid fish. PhD thesis, Oregon State University, Corvallis

Holt RA, Rohovec JS, Fryer JL (1993) Bacterial coldwater disease. In: Inglis V, Roberts RJ, Bromage NR (eds) Bacteria diseases of fish. Blackwell Scientific Publications, Oxford p 3-23

Lorenzen E (1994) Studies on Flexibacter psychrophilus in relation to rainbow trout fry syndrome (RTFS). PhD thesis National Veterinary Laboratory, Aarhus, Royal Veterinary and Agricultural University, Copenhagen

Lorenzen E, Olesen NJ (1997) Characterization of isolates of Flavobacterium psychrophilum associated with coldwater disease or rainbow trout fry syndrome II: serological studies. Dis Aquat Org 31:209-220

Lorenzen E, Dalsgaard I, Bernardet JF (1997) Characterization of isolates of Flavobacterium psychrophilum associated with coldwater disease or rainbow trout fry syndrome I: phenotypic and genomic studies. Dis Aquat Org 31 $197-208$

Madsen L, Dalsgaard I (1998) Characterization of Flavobacterium psychrophilum; comparison of proteolytic activity and virulence of strains isolated from rainbow trout (Oncorhynchus mykiss). In: Barnes AC, Davidson GA, Hiney MP, McIntosh D (eds) Methodology in fish diseases research. Fisheries Research Services, Aberdeen, p 45-52

Nordmo R (1997) Strengths and weaknesses of different challenge methods. In: Gudding R, Lillehaug A, Midtlyng PJ, Brown $F$ (eds) Fish vaccinology. Dev Biol Stand 90 303-309

Otis EJ (1984) Lesions of coldwater disease in steelhead trout (Salmo gairdneri): the role of extracellular products. MSc thesis, University of Rhode Island, Kingston

Rangdale RE (1995) Studies on rainbow trout fry syndrome (RTFS). PhD thesis, Ministry of Agriculture, Fisheries and Food, Weymouth, University of Stirling

Tatner MF (1996) Natural changes in the immune system of fish. In: Iwama $G$, Nakanishi $T$ (eds) The fish immune systemi organism, pathogen, and environment. Academic Press, London, p 255-287

Submitted: November 17, 1998; Accepted: March 1, 1999 Proofs received from author(s): May 17, 1999 